Michał Zawadzki

Uniwersytet Jagielloński, Instytut Kultury

\title{
Denaturalizacja racjonalności instrumentalnej w edukacji menedżerskiej w Polsce
}

\author{
Wprowadzenie
}

Z perspektywy kulturowej odpowiedzialności roli menedżera nie jest bez znaczenia jakość edukacji, która przygotowuje do jej pełnienia. Edukacja menedżerska ${ }^{1}$ realizująca funkcję wdrażania do uczestnictwa w kulturze, $\mathrm{w}$ tym do partycypacji w rzeczywistości organizacyjnej, musi umożliwiać ciągły rozwój krytycznej refleksyjności przez osoby w nią zaangażowane. Zarówno jakość komunikacji pomiędzy osobami uwikłanymi $\mathrm{w}$ proces kształcenia, zaangażowane wartości czy treści użyte w procesie edukacji, mają kluczowe znaczenie dla jakości kompetencji kulturowych i poziomu kapitału symbolicznego, które rozstrzygają o stopniu krytycznej refleksyjności decydującej o odpowiedzialności i wrażliwości etycznej oraz kulturowej, które stanowią kryterium efektywności działania w organizacji. Rola menedżera wiąże się bowiem ze zdolnością do rozpoznawania normatywnego charakteru i strukturalnej złożoności tak rzeczywistości, jak i realizowanych celów w trosce nie tylko o ekonomiczną sprawność organizacji, ale przede wszystkim o kondycję egzystencjalną podmiotów zaangażowanych w działanie ${ }^{2}$.

Niestety edukacja menedżerska w Polsce zdominowana jest współcześnie przez imperatyw techniczny, lokujący główne założenia normatywne kształcenia menedżerskiego na płaszczyźnie racjonalności instrumentalnej. Używane treści kształcenia mają charakter przeekonomizowany i przestarzały, lokując się w profilu paradygmatu funkcjonalizmu i pozytywizmu. Komunikacja pomiędzy nauczycielami a studentami, a także kontakt z kulturą symboliczną mają charakter pozorny, sprowadzając się do pamięciowego zapamiętywania informacji. Stu-

\footnotetext{
1 Pod pojęciem edukacji menedżerskiej w Polsce rozumiem zarówno studia ekonomiczne, jak i studia z zakresu zarządzania (na prywatnych i państwowych uczelniach wyższych), a także studia podyplomowe, $\mathrm{w}$ tym MBA.

L. Witkowski, Jak pokonać 'homo oeconomicus'? (problem specyfiki zarzadzania humanistycznego), [w:] Humanistyka i zarządzanie. W poszukiwaniu problemów badawczych i inspiracji metodologicznych, pod red. P. Górskiego, Wydawnictwo UJ, Kraków 2009, s. 115.
} 
denci zamiast uczyć się sprawnego zarządzania organizacją, w tym innymi ludźmi, co wymaga rozwiniętych kompetencji kulturowych i wyobraźni humanistycznej pozwalających dostrzegać złożoność życia organizacyjnego i troszczyć się o dobro drugiego człowieka, uczą się jedynie kalkulować zyski i straty oraz traktować innych ludzi w organizacji jak zasób konieczny do realizacji celu ekonomicznego. Szerzący się wśród polskich menedżerów analfabetyzm kulturowy wynika w dużej mierze z faktu, iż edukacja menedżerska, którą kończą, stanowi pozór kształcenia zamaskowany domniemanym prestiżem dyplomu, miejsca instytucji kształcącej w rankingu i wysokiego czesnego (co szczególnie widać w przypadku studiów $\left.\mathrm{MBA}^{3}\right)$.

Interesującym, choć w Polsce nierozpoznanym narzędziem badawczym, pozwalającym diagnozować patologie edukacji menedżerskiej i proponować zmiany na jej gruncie, jest nurt krytycznej edukacji menedżerskiej („Critical Management Education"), który czerpie podstawowe założenia z pedagogiki radykalnej i jednocześnie stanowi najważniejsze pole emancypacyjne dla szerszego nurtu krytycznego w naukach o zarządzaniu („Critical Management Studies”). W niniejszym artykule przybliżam ideę obu nurtów, omawiam fundujące je założenia, a także przy pomocy proponowanych przez nie narzędzi krytycznych podejmuję próbę krytycznej diagnozy obecnego stanu edukacji menedżerskiej w Polsce. Celem podjętej refleksji jest przede wszystkim wskazanie złudzenia naturalności usytuowania założeń normatywnych edukacji menedżerskiej na racjonalności instrumentalnej, w tym ukazanie patologii kulturowych wynikających $\mathrm{z}$ tego usytuowania oraz wskazanie alternatywy w postaci racjonalności emancypacyjnej. Refleksja została oparta na własnych badaniach teoretycznych, w których posiłkuję się ideami etyki czytania, autorytetu symbolicznego oraz triady rozwoju moralnego autorstwa Lecha Witkowskiego. W refleksji wykorzystuję również zastane badania empiryczne dotyczące polskich menedżerów i edukacji menedżerskiej.

\section{Nurt krytyczny w naukach o zarządzaniu}

\section{Źródła}

Nurt krytyczny w naukach o zarządzaniu („,Critical Management Studies”) 4 to transdyscyplinarna płaszczyzna krytycznej refleksji humanistycznej nad teorią i praktyką zarządzania i organizowania. Nurt ten przyjął formę zinstytucjonalizowaną na początku lat dziewięćdziesiątych dwudziestego wieku i choć w zachodnim dyskursie zarządzania zyskuje coraz większą popularność, w polskim jest

\footnotetext{
3 MBA - Master of Business Administration.

4 The Oxford Handbook of Critical Management Studies, H. Willmott, M. Alvesson, T. Bridgman (eds), Oxford University Press, Oxford 2009.
} 
słabo rozpoznanym obszarem ${ }^{5}$.Źródła intelektualne nurtu krytycznego są bardzo szerokie i przede wszystkim obejmują teorię krytyczną szkoły frankfurckiej, postmodernizm, poststrukturalizm, krytyczny realizm, pedagogikę radykalną, studia kulturowe i feminizm. Pomimo mnogości źródeł zasilających nurt krytyczny, które ewoluowały i pluralizowały się wraz z rozwojem nurtu (i które często nachodzą na siebie zakresem proponowanych rozwiązań normatywnych), podstawowym źródłem stanowiącym bazę dla wysiłków poznawczych pozostaje teoria krytyczna szkoły frankfurckiej'.

Na płaszczyźnie krytycznych studiów zarządzania możemy wyróżnić dwa główne podejścia związane z adaptacją teorii krytycznej szkoły frankfurckiej do badania świata zarządzania i organizowania7. Pierwsze wiąże się z krytyką ideologii i nawiązuje do wczesnych prac badaczy wywodzących się z tej szkoły. Głównym punktem zainteresowania $\mathrm{w}$ tym podejściu jest bazująca na teorii marksistowskiej krytyka ideologii menedżeryzmu, uwypuklająca problem wykorzystywania pracowników przez menedżerów. Koncepcje bazujące na tym podejściu ukierunkowane są przede wszystkim na krytykę następujących procesów: naturalizacja i uniwersalizacja interesów menedżerskich, prymat instrumentalnego rozumu i hegemonia władzy.

Choć nurt krytyczny czerpie inspiracje z wczesnej szkoły frankfurckiej, badacze zwracają uwagę na niedostatki jej propozycji w kontekście namysłu nad światem zarządzania. Przedstawiciele tej szkoły, tacy jak Max Horkheimer i Theodor Adorno na przykład niewielką uwagę poświęcili problemom związanym z pracą menedżera, a jeśli zajmowali się tym tematem, to zazwyczaj traktowali menedżerów jako homogeniczną grupę agentów kapitalizmu, którzy uciskają pracowników w celu maksymalizacji własnych zysków. Owa idea czerpiąca swoje źródło z marksizmu nie pozwala widzieć faktu, iż sami menedżerowie mogą być uciskani, a także tego, że w organizacji mogą istnieć różne poziomy zarządzania wraz z różnymi rolami organizacyjnymi ${ }^{8}$.

Drugie podejście do krytycznych badań nad zarządzaniem i organizowaniem wiąże się z wykorzystaniem inspiracji poznawczych wynikających z przeformułowania paradygmatu teorii krytycznej przez Jürgena Habermasa. Choć w tym podejściu również można odnaleźć elementy związane z krytyką ideologii, to jed-

5 Zob. Ł. Sułkowski, Epistemologia i metodologia zarządzania, PWE, Warszawa 2012; M. Zawadzki, Rola i miejsce nurtu krytycznego w naukach o zarządzaniu, „Culture Management / Kulturmanagement / Zarządzanie Kulturą", vol. 5 (w druku); M. Zawadzki, Teoria krytyczna w epistemologii nauk o zarządzaniu, „Przedsiębiorczość i Zarządzanie” 2011, t. XII, z. 12, s. 13-28.

6 A.G. Scherer, Critical Theory and Its Contribution to Critical Management Studies, [w:] The Oxford Handbook of Critical Management Studies, H. Willmott, M. Alvesson, T. Bridgman (eds), Oxford University Press, Oxford 2009, s. 29-51.

7 M. Alvesson, S. Deetz, Critical Theory and Postmodernism: Approaches to Organization Studies, [w:] Critical Management Studies. A Reader, Ch. Grey, H. Willmott (eds), Oxford University Press, Oxford 2005, s. 60-106.

J. Duberley, P. Johnson, Understanding Management Research: An Introduction to Epistemology, Sage Publications, London 2003, s. 123. 
nak punkt ciężkości w wykorzystaniu teorii krytycznej na płaszczyźnie zarządzania zostaje przeniesiony na diagnozę dyskursu zarządzania w kontekście trójkąta interesów poznawczych', a także na wykorzystanie koncepcji idealnej sytuacji komunikacyjnej do diagnozy prób reformowania instytucji poprzez etycznie zorientowany dyskurs ${ }^{10}$. W pierwszym przypadku badania koncentrują się na płaszczyźnie epistemologii zarządzania i polegają na krytycznej diagnozie paradygmatów obecnych w naukach o zarządzaniu, w celu ukazania konsekwencji wynikających z przyjmowania określonych założeń normatywnych. W drugim przypadku głównym punktem zainteresowania jest badanie komunikacji organizacyjnej pod kątem możliwości wyeliminowania zakłóceń komunikacyjnych w kontekście ukonstytuowania typu komunikacji stanowiącego podstawę dla racjonalnego, refleksyjnego i moralnego podejmowania decyzji. Ponadto krytyczna analiza komunikacji w organizacji pozwala na diagnozę roli określonych sposobów zarządzania w podwyższaniu lub obniżaniu jakości komunikacji.

\section{Założenia normatywne}

Nurt krytyczny oparty na założeniu konieczności troski o człowieka jako uczestnika świata organizacji szczególnie ukierunkowany jest na diagnozę społecznych i kulturowych warunków relacji dominacji czy opresji w organizacji, które nierzadko stanowią efekt procesów zarządzania. Warunki te rozpatrywane są jako elementy składowe takich patologii kulturowych w organizacji, jak ideologia menedżeryzmu, instrumentalne podejście do człowieka czy hegemonia ekonomizmu. W związku z krytyczną i humanistyczną orientacją centralnymi zagadnieniami dla nurtu krytycznego są: pojęcie racjonalności i postępu, technokracja i społeczna inżynieria, autonomia i kontrola, działanie komunikacyjne, władza i ideologia, wartość oporu, a także fundamentalne dla konstrukcji wiedzy z dyscypliny zarządzania kwestie epistemologiczne. Prowadząc badania nad tymi zagadnieniami, badacze kierują się intencją humanizacji dyskursu zarządzania, a także troską o poprawę warunków pracy na mocy demokratyzacji relacji społecznych, co wiązałoby się z koniecznością ukonstytuowania refleksyjnego i emancypacyjnego wymiaru ludzkiego bycia w organizacji.

Nurt krytyczny w naukach o zarządzaniu charakteryzuje się specyficznymi cechami, które pozwalają odróżnić krytyczność badań prowadzonych z perspektywy tego nurtu od innych badań prowadzonych w naukach o zarządzaniu.

\footnotetext{
9 J. Habermas, Knowledge and Human Interests, Beacon Press, Boston 1972; H. Willmott, Organization Theory as a Critical Science? Forms of Analysis and 'New Organizational Form', [w:] The Oxford Handbook of Organization Theory: Meta-theoretical Perspectives, Ch. Knudsen, H. Tsoukas (eds), Oxford University Press, Oxford-New York 2005, s. 88-112.

10 J. Habermas, Teoria działania komunikacyjnego, tłum. A.M. Kaniowski, PWN, Warszawa 2002; J. Forester, On Fieldwork in a Habermasian Way: Critical Ethnography and the Extra-ordinary Character of Ordinary Professional Work, [w:] Studying Management Critically, H. Willmott, M. Alvesson (eds), Sage Publications, London 2003, s. 46-65.
} 
Nurt ten nie rości sobie prawa do wskazywania jedynego prawdziwego znaczenia krytyki (byłby to zabieg zgodny z myśleniem pozytywistycznym, które stanowi główny obiekt krytyki $\mathrm{CMSu}^{11}$ ) - ale argumentuje jedynie za jej rozumieniem wywodzącym się przede wszystkim z teorii krytycznej szkoły frankfurckiej, które znacząco różni się od potocznego rozumienia tego pojęcia w badaniach naukowych, stojąc wobec niego w opozycji i wskazując na jego braki.

Jak przewrotnie zauważa Alessia Contu ${ }^{12}$, we współczesnej cywilizacji szybkości, innowacji i hiperrefleksyjności (aczkolwiek chodzi tu o refleksyjność zredukowaną do wymiaru oswajania szumu informacyjnego, niemającego nic wspólnego z wiedzą wymagającą przeżycia i krytycznego oglądu) nikt (a szczególnie naukowiec) nie zadeklaruje się przecież jako bezkrytyczny konformista czy dogmatyk. Jednak z perspektywy teorii krytycznej przyznanie sobie miana bycia krytycznym tylko ze względu na pełnioną rolę (naukowiec) czy ilość oswajanych informacji jest nieodpowiedzialną uzurpacją. Krytyczność wymaga bowiem podjęcia określonych strategii względem rzeczywistości w procesie jej badania i zmiany. Adaptacja teorii krytycznej szkoły frankfurckiej na grunt zarządzania pozwala wskazać na kilka z nich. Są to: denaturalizacja, antyperformatywność i refleksyjność, a także idea zaangażowania badań naukowych w proces dążenia do zmiany społecznej na mocy procesów emancypacji ${ }^{13}$.

Denaturalizacja (denaturalization) - podstawowa strategia badawcza w nurcie krytycznym, z której wynikają pozostałe - ukierunkowana jest na podanie w wątpliwość tych elementów związanych z zarządzaniem i organizowaniem, które uznane są powszechnie za naturalne, oczywiste i dla których uznaje się, że nie ma alternatywy (there is no alternative). Badacze podejmują zatem wysiłek ukazywania uzależnienia każdej refleksji oraz działania od partykularnych kontekstów czy interesów, innymi słowy: wskazują na ich nieuchronnie polityczny i normatywny walor. Idzie to w parze z przyjęciem antyperformatywnego stanowiska i zaprzeczeniem, jakoby relacje społeczne w organizacji powinny być rozpatrywane jako wyłącznie instrumentalne, to znaczy analizowane w terminach maksymalizacji wyników za pomocą określonych środków. Na przykład uznanie, że jakość procesów zarządzania czy pracy menedżera uzależnione są jedynie od zdolności do osiągania wzrostu efektywności ekonomicznej organizacji, prowadzi do odpolitycznienia refleksji na temat procesów zarządzania i organizowania. Pomija się bowiem w ten sposób głębsze etyczne i polityczne kwestie, takie jak dystrybucja szans życiowych w organizacji czy stopień demokratyzacji relacji wewnątrzorganizacyjnych.

\footnotetext{
11 Dziękuję Panu doktorowi Piotrowi Zamojskiemu za zwrócenie mojej uwagi na ten problem w trakcie kuluarowych rozmów podczas gdańskiej konferencji „Pedagogika krytyczna dziś. Pytania o teorię i praktykę" (Instytut Pedagogiki Uniwersytetu Gdańskiego, 28-29 maja 2012 r.).

12 A. Contu, Critical Management Education, [w:] The Oxford Handbook of Critical Management Studies, H. Willmott, M. Alvesson, T. Bridgman (eds), Oxford University Press, Oxford 2009, s. 538.

13 C. Grey, V. Fournier, At the critical moment: Conditions and prospects for critical management studies, „Human Relations” 2000, no. 53 (1), s. 7-32.
} 
Wiedza dotycząca zarządzania musi zatem zostać uwolniona od dominacji racjonalności instrumentalnej - kryterium wartości wiedzy nie może być jedynie praktyczna użyteczność oparta na regułach efektywnościowych. W przywracaniu etycznego wymiaru wiedzy w naukach o zarządzaniu pomóc może postulat refleksyjności (reflexivity), który odnosi się do zdolności widzenia wszystkich zagadnień dotyczących organizacji i zarządzania jako zapośredniczonych przez partykularną tradycję ich autorów, w tym przez przyjmowane przez nich rozstrzygnięcia o charakterze założeń filozoficznych. Tym samym zanegowane zostaje spojrzenie na wiedzę i prawdę jako obiektywny i autorytatywny wynik pojedynczej racjonalności naukowej na rzecz konstruktywizmu i epistemologicznego pluralizmu.

Nurt krytyczny wskazuje zatem na nieuchronność przyjmowania określonych wartości na każdym etapie procesu badawczego w naukach o zarządzaniu, podkreślając jednocześnie, że oddzielanie wartości od faktów, mające na celu spełnienie warunków obiektywizmu procesu badawczego, to pozytywistyczna i niemożliwa do spełnienia iluzja. Badacz nie jest neutralnym obserwatorem, lecz $\mathrm{w}$ proces badawczy zawsze nieuchronnie angażuje osobiste wartości, które wpływają na ten proces i na rezultaty badań.

Denaturalizacja, antyperformatywność i refleksyjność wiążą się ze zobowiązaniem względem praxis. Jest to jeden z najważniejszych warunków realizacji celu emancypacyjnego stanowiącego motyw przewodni dla produkcji intelektualnej nurtu krytycznego. Emancypacja jest tu rozumiana jako uświadomienie sobie lub innym ludziom (pracownikom, menedżerom, naukowcom, studentom) niekonieczności przyjmowania dehumanizacyjnych założeń w myśleniu i działaniu i/lub niekonieczności bytowania w uwłaczających podmiotowości i godności warunkach, z jednoczesną intencją zmiany pozwalającej na głębszą troskę o człowieczeństwo i podmiotowość. Dążenie do zmiany rzeczywistości (w tym organizacyjnej) to jedna z podstawowych cech, która odróżnia krytyczność nurtu "Critical Management Studies" od innych koncepcji i teorii krytycznych. Celem nurtu krytycznego nie jest zatem jedynie inne, krytyczne spojrzenie na świat zarządzania, ale przede wszystkim dążenie do wprowadzenia zmian $\mathrm{w}$ teorii i praktyce zarządzania i organizowania - również poprzez zmiany na płaszczyźnie edukacji, w tym edukacji menedżerskiej ${ }^{14}$.

\section{Pola interwencji}

Konstruktywistyczne stanowisko nurtu krytycznego w naukach o zarządzaniu pozwala na projektowanie badań i metodologii badawczej w kierunku reali-

14 M. Zawadzki, Autorytet symboliczny jako wyzwanie dla edukacji menedżerskiej i nauk o zarzadzaniu, [w:] Pedagogika i zarządzanie edukacja i rozwojem. W perspektywie troski o uniwersytet $i$ kulturę humanistyczna, pod red. L. Witkowskiego, M. Jaworskiej-Witkowskiej, seria: „Przebudzenia Humanistyczne. Kolokwia", t. I, Wydawnictwo Adam Marszałek, Torun 2010, s. 222-248. 
zacji postulatów upełnomocnienia i emancypacji. Postulaty te realizowane są w odniesieniu do trzech głównych płaszczyzn dyskursywnych i grup docelowych: płaszczyzna naukowego dyskursu zarządzania i naukowcy (badacze), płaszczyzna dyskursu organizacyjnego i pracownicy organizacji ( $w$ tym menedżerowie), płaszczyzna dyskursu edukacji menedżerskiej i studenci wraz z nauczycielami.

Orientacja badawcza nurtu krytycznego na dyskurs naukowy ukierunkowana jest przede wszystkim na diagnozę płaszczyzny epistemologicznej nauk o zarządzaniu, gdzie przedmiotem badań krytycznych są założenia przyjmowane $\mathrm{w}$ procesach badawczych oraz składające się na wiedzę dotyczącą zarządzania i organizowania ${ }^{15}$. Korzystając z perspektywy konstruktywistycznej badacze sytuujący swoje badania $\mathrm{w}$ nurcie krytycznym podkreślają, że sama konstrukcja wiedzy z dyscypliny nauk o zarządzaniu wpływa na dyskurs zarządzania, kształtując nie tylko założenia stanowiące podstawę dla badań naukowych, ale i świadomość środowiska naukowego, zarządzania i konsultantów, a także - ostatecznie - sposób funkcjonowania organizacji ${ }^{16}$.

Badania z zakresu nurtu krytycznego w naukach o zarządzaniu mogą być również przeprowadzane bezpośrednio w organizacji. Najczęściej przybierają one wtedy formę krytycznej etnografii ukierunkowanej na procesy denaturalizacji zastanego porządku i krytyki dominującej ideologii. Procesy te bezpośrednio wiążą się z celem emancypacyjnym badań krytycznych: badania te nie tylko zmierzają do konstrukcji użytecznej wiedzy na podstawie diagnozy problemu badawczego i analizy rzeczywistości, ale mają także na celu wpłynąć na postawy i świadomość badanych ludzi, którzy włączani są w proces badawczy ${ }^{17}$.

Płaszczyzna edukacji - w porównaniu $\mathrm{z}$ dwiema pozostałymi - jest najbardziej skutecznym i wpływowym polem do dokonywania zmian, ze względu na możliwość długoterminowego wprowadzania impulsów emancypacyjnych, opartego na wzroście kapitału kulturowego, warunkując realność i głębokość oddziaływania. Troska o refleksyjny i emancypacyjny wymiar bycia w organizacji łączy się w tym wypadku z pogłębioną refleksją nad płaszczyzną edukacji menedżerskiej, spełniającą kluczową rolę w wyposażaniu podmiotów w kompetencje kulturowe, decydujące o zdolności do upominania się o (swój lub innych podmiotów) emancypacyjny wymiar bycia w organizacji. Badania nad tym wymiarem zasilane są przez nurt krytycznej edukacji menedżerskiej - „Critical Management Education”, który czerpie swoje podstawowe założenia filozoficzne z pedagogiki

15 M. Alvesson, S. Deetz, Doing Critical Management Research, Sage Publications, London 2000.

16 N. Harding, The Social Construction of Management. Texts and Identities, Routledge, London-New York 2003.

17 J. Duberley, P. Johnson, Critical Management Methodology, [w:] The Oxford Handbook of Critical Management Studies, H. Willmott, M. Alvesson, T. Bridgman (eds), Oxford University Press, Oxford 2009 , s. 345-368. 
radykalnej ${ }^{18}$. Kluczowe są $\mathrm{w}$ tym kontekście idee emancypacji oraz upełnomocnienia, które wskazują na fakt, że od jakości realizacji przez edukację misji kulturowej związanej z wdrażaniem jednostek do uczestnictwa w kulturze zależy urzeczywistnienie emancypacyjnego wymiaru uczestnictwa w sferze publicznej $-w$ tym organizacyjnej.

\section{Patologie kulturowe w edukacji menedżerskiej w Polsce}

\section{Edukacja i zarządzanie w perspektywie racjonalności instrumentalnej}

Korzystając z typów racjonalności Jürgena Habermasa ${ }^{19}$, a także z opartej na nich koncepcji typów racjonalności Henry Girouxa ${ }^{20}$, należy zauważyć, że główną patologią edukacji menedżerskiej w Polsce jest oparcie jej założeń normatywnych na imperatywie technicznym, z dominacją racjonalności instrumentalnej jako warunkującą procesy kształcenia. Racjonalność rozumiem za Girouxem jako „określony zbiór założeń oraz praktyk społecznych, które pośredniczą w sposobie, $\mathrm{w}$ jakim jednostka lub grupa odnoszą się do szerszego społeczeństwa. U podstaw każdego typu racjonalności leży zbiór interesów, które określają, jak odzwierciedla się świat"21.

Dominacja racjonalności instrumentalnej (lub jak woli Giroux: technicznej lub technokratycznej) skutkuje przede wszystkim rytualizacją pozoru apolityczności edukacji i przekazywanej w jej ramach wiedzy. Model edukacji oparty na przewadze tego typu racjonalności charakteryzuje się brakiem refleksyjności na temat przyjmowanych $w$ jego ramach założeń normatywnych, a także (tym samym) bezrefleksyjnym przekonaniem o niepodważalnej słuszności tych założeń i ich uniwersalnej obowiązywalności. Socjalizacja w takim modelu kształcenia sprowadza się do przygotowania jego odbiorców do urzeczowiania odpowiednich środków, które pozwolą na realizację niepodważalnych celów. Odbywa się to poprzez odkrywanie "faktów" mówiących, jak rzeczy mają się naprawdę - wszystko to, co znajduje się poza sferą "faktów”, uznawane jest za bezwartościową spekulację. Jak zauważa Giroux, „pytanie, kto nadaje prawomocność 'faktom' danego porządku społecznego, $\mathrm{w}$ tym wypadku jest usunięte $\mathrm{z}$ kontekstu pedagogiki w klasie szkolnej i z dyskusji" 22.

18 A. Contu, Critical Management Education, [w:] The Oxford Handbook of Critical Management Studies, H. Willmott, M. Alvesson, T. Bridgman (eds), Oxford University Press, Oxford 2009, s. 536-550; C. Grey, Reinventing Business Schools: The Contribution of Critical Management Education, "Academy of Management Learning and Education" 2004, vol. 3, no. 2, s. 178-186.

19 J. Habermas, Knowledge and Human Interests, Beacon Press, Boston 1972.

20 H.A. Giroux, Teoria krytyczna i racjonalność w edukacji obywatelskiej, tłum. P. Kwieciński, A. Nalaskowski, [w:] Edukacja i sfera publiczna. Idee i doświadczenia pedagogiki radykalnej, pod red. H.A. Girouxa, L. Witkowskiego, Oficyna Wydawnicza „Impuls”, s. 149-184.

21 H.A. Giroux, Teoria krytyczna..., s. 153.

22 Ibidem, s. 160. 
Produkcja wiedzy ukierunkowana jest zatem na wzrost efektywności i wydajności środków w kontekście dążenia do realizacji z góry ustalonych celów - nie pojawia się jednak pytanie ani o prawomocność przyjmowanych celów, ani o słuszność takiego postępowania analitycznego. Rzeczywistość pojmowana jest jako zestaw niezależnych, zewnętrznych, obiektywnych i stałych elementów czy procesów możliwych do odkrycia i manipulowania przez człowieka, który dąży do poszerzania swojej kontroli nad światem. Elementy te pojmowane są jako manipulowalne i współzależne zmienne, natomiast wartość danej teorii uzależniana jest od jej użyteczności w kontekście kontroli środowiska i produkowania przewidywalnych efektów. Nauczyciel w tej orientacji jest jedynie pasywnym przekaźnikiem wiedzy, a nie negocjatorem sensów dotyczących rzeczywistości.

Edukacja menedżerska w Polsce nastawiona jest głównie na przygotowywanie jednostek do umiejętności kalkulacji tak swojego, jak i organizacyjnego interesu i do działania w zgodzie z ustalonymi procedurami w kontekście realizacji z góry narzuconego celu. Podstawowym problemem jest przeważająca obecność stechnicyzowanych, opartych na paradygmacie pozytywistycznym treści kształcenia, akcentujących techniki efektywności ekonomicznej, kosztem rozwoju wyobraźni humanistycznej na mocy kontaktu z treściami humanistycznymi, nie wspominając o braku otwartości podmiotów na realne przeżywanie tych treści ${ }^{23}$. Tym samym edukacja ta nie stwarza warunków do nabywania kompetencji kulturowych i poszerzania kapitału symbolicznego, koniecznych do działania w złożonej rzeczywistości i do sprawnego zarządzania, które stanowi społeczno-kulturowy proces nadawania sensu rzeczywistości ${ }^{24}$.

Zakłada się, że praktyka zarządzania wymaga jedynie instrumentalnych umiejętności, które mają pozwolić na racjonalne działanie ukierunkowane na bezkrytyczną realizację odpowiednich środków, co prowadzić ma na mocy relacji przyczynowo-skutkowej do urzeczywistniania przyjmowanego w sposób bezalternatywny celu ekonomicznego. Innymi słowy, na płaszczyźnie podstawowych założeń fundujących współczesną edukację menedżerską w Polsce przyjmuje się model homo oeconomicus ${ }^{25}$ jako idealny konstrukt dla projektowania roli menedżera: niezależnie od złożoności dylematów o charakterze normatywnym menedżer ma dążyć do maksymalizacji subiektywnie oczekiwanych skutków swoich działań, przy czym działania te zredukowane są jedynie do poszukiwania środków koniecznych do realizacji efektywności ekonomicznej. Jednym ze skutków tego stanu rzeczy jest brak problematyzującego wymiaru kształcenia, redukowanego zazwyczaj do jałowej kulturowo strategii socjalizowania do gotowych recept czy rozwiązań, które uznaje się za niepodważalne

23 Co widoczne jest nie tylko na gruncie edukacji menedżerskiej w Polsce, ale i na Zachodzie, zob. J. Hendry, Management education and the humanities: The challenge of post-bureaucracy, [w:] Management education and humanities, pod red. B. Czarniawskiej, P. Gagliardi, E. Elgara, Cheltenham-Northampton 2006, s. 21-44.

24 S. Magala, The Management of Meaning in Organizations, Palgrave Macmilian, New York 2009.

25 Zob. L. Witkowski, Jak pokonać 'homo oeconomicus'?... , s. 115-142. 
fakty pozwalające manipulować rzeczywistością. Idzie to $\mathrm{w}$ parze $\mathrm{z}$ brakiem podejmowania krytycznej refleksji i dyskusji nad omawianymi treściami lub redukowaniem takiej refleksji jedynie do instrumentalnego zagadnienia potencjału danego rozwiązania teoretycznego w kontekście dążenia do realizacji celu ekonomicznego w organizacji.

Należy zauważyć, że już sam charakter treści serwowanych na gruncie edukacji menedżerskiej w Polsce reprodukuje niezdolność do autonomicznego myślenia, usprawiedliwianą jednak domniemanym autorytetem tych treści. Kluczowa jest w tym kontekście uwaga Lecha Witkowskiego za Hansem Georgem Gadamerem, że „wykładnia jakiegoś tekstu pełni czasem funkcję normatywną (...), narzucając swoje ujęcie jako obowiązujące"26. Sama konstrukcja wykorzystywanych $\mathrm{w}$ procesie dydaktycznym treści nasiąkniętych pozytywistycznymi schematami, perswazyjnie komunikującymi o ich rzekomym obiektywizmie i uniwersalnej ważności, generuje złudzenie o ich autorytatywności i w konsekwencji uruchamia mechanizm zwolnienia z krytycznej refleksyjności nad tym, co proponują.

Symptomatyczna jest $\mathrm{w}$ tym kontekście konstrukcja polskich podręczników z zarządzania wykorzystywanych w edukacji menedżerskiej. Jak zauważa Sławomir Banaszak: „(...) prezentują one albo wyłącznie pozytywną stronę zarządzania, w ramach której nawet trudności mogą być przezwyciężone dzięki zastosowaniu odpowiedniego algorytmu działania, albo próbują ukazać rzeczywistość (społeczną, gospodarczą, organizacyjną) jako nieskomplikowaną, której ewentualne zawiłości i przeciwności są związane z niezrozumieniem jej przez uczestników organizacyjnego życia" ${ }^{27}$. Idzie to w parze z przeekonomizowanym punktem widzenia (ekonomia traktowana jako recepta na wszelkie problemy organizacyjne), który dodatkowo przedstawiany jest jako jedynie obowiązujący.

Powyższa patologia idzie w parze z brakiem inicjowania realnej dyskusji problematyzującej nabywane treści, co ostatecznie redukuje edukacyjny wymiar kształcenia do kumulatywnego gromadzenia nieproblematycznych informacji, które w takim wypadku, jak czytamy za Erichem Frommem, przybierają formę wyalienowaną, ponieważ przyznaje się im prawdziwość tylko dlatego, że pochodzą od uznanego autorytetu ${ }^{28}$. Wiedza wyalienowana to efekt "scholastycznego czytania" 29 , gdzie realny dialog z autorytetem symbolicznym zastępowany jest przez jego bezkrytyczne uwznioślenie.

Mechanizm zwalniania z refleksyjności pod wpływem wygodnego podporządkowania się autorytetowi wzmacnia obecność w programach kształcenia

26 L. Witkowski, Wyzwania autorytetu w praktyce społecznej $i$ kulturze symbolicznej (przechadzki krytyczne w poszukiwaniu dyskursu dla teorii), Oficyna Wydawnicza „Impuls”, Kraków 2009, s. 190.

27 S. Banaszak, Edukacja menedżerska w społeczeństwie wspótczesnym. Studium teoretyczno-empiryczne, Wydawnictwo Naukowe UAM, Poznań 2011, s. 171-172.

28 E. Fromm, Wolność, determinizm, alternatywizm, tłum. A. Żuk, „Colloquia Communia” 1990, nr 1-6(48-53), s. 105; cyt. za: L. Witkowski, Wyzwania autorytetu..., s. 131.

29 L. Witkowski, Wyzwania autorytetu ..., s. 168. 
menedżerskiego nienaukowych poradników pisanych przez osoby uznawane za guru zarządzania. Jak analizują ten problem John Micklethwait i Adrian Wooldridge: „tam, gdzie teoria zarządzania miesza się z przemysłem poradników, guru gmerają w ludzkich umysłach, ucząc innych, co mają myśleć na każdy temat, od porządków na biurku do życia intymnego" ${ }^{\prime 30}$. Kategoryczne stwierdzenia mające sugerować „,jak jest naprawdę" i co trzeba zrobić, aby odnieść sukces w organizacji, to konstytutywny element tak książek guru zarządzaniais ${ }^{31}$, jak i prowadzonych przez nich seminariów, które z uwagi na wysoką cenę i niewymagający głębszego wysiłku myślowego przekaz stają się atrakcyjne i przyciągają chętnych do bezrefleksyjnego naśladowania.

\section{Edukacja menedżerska w perspektywie triady rozwoju moralnego Habermasa-Kohlberga}

Konsekwencje wynikające $z$ dominacji racjonalności instrumentalnej w edukacji menedżerskiej w Polsce warto rozpatrzyć w kontekście implikacji wynikających z rekonstrukcji koncepcji triady rozwoju moralnego Jürgena Habermasa i Lawrence'a Kohlberga dokonanej przez Lecha Witkowskiego ${ }^{32}$ oraz związanych z tą koncepcją typów wspólnoty, gdzie dany typ wspólnoty utożsamiam z danym typem organizacji. Wydaje się zasadne stwierdzenie, że dominujący w Polsce model edukacji menedżerskiej socjalizuje studentów do profilu przedkonwencjonalnej "wspólnoty interesów” (organizacja interesów) oraz konwencjonalnej „wspólnoty zadań" (organizacja zadaniowa).

„Wspólnota interesów" charakteryzuje się silnym naciskiem na zbieżność partykularnie definiowanych interesów i stanowi środek do realizacji celów „odnoszonych do egoistycznie postrzeganego interesu i pożądanego efektu doraźnie wspólnie podejmowanych działań" ${ }^{\prime 3}$. Wspólnota ta konstytuowana jest przez jednostki znajdujące się na przedkonwencjonalnym - a więc najniższym - poziomie moralności, związanym z przyjęciem "orientacji radarowej" w przestrzeni społecznej. Orientacja ta „wyraża (...) gotowość do uzgadniania i realizowania interesu własnego z każdym interesem aktualnie dominującym w (...) otoczeniu"34. Jednostka funkcjonuje zatem na poziomie strategii korzyści-strat, starając się działać według logiki unikania kar i indywidualnej opłacalności podejmowanych działań (strategia „świętego spokoju”).

${ }^{30}$ A. Wooldridge, J. Micklethwait, Szamani zarządzania, tłum. A.M. Unterschuetz, Wyd. Zysk i S-ka, Poznań 2000., s. 9.

31 Zob. np. T. Peters, R. Waterman, In Search of Excellence: Lessons from America's Best-Run Companies, Harper \& Row, New York 1982.

32 L. Witkowski, Tożsamość i zmiana. Epistemologia i rozwojowe profile w edukacji, Wydawnictwo Naukowe Dolnośląskiej Szkoły Wyższej, Wrocław 2010.

33 Ibidem, s. 166.

34 Ibidem, s. 182. 
Z kolei „wspólnota zadań” stanowi zadaną realność, która zorganizowana została i funkcjonuje wokól sztywno ustalonych celów i zadań „nadrzędnych wobec partykularnych perspektyw jednostek funkcjonujących w niej"35. Wspólnota ta konstytuowana jest przez jednostki znajdujące się na konwencjonalnym poziomie rozwoju moralnego, które działają według logiki aprobaty dla norm i wartości grupowych (organizacyjnych) na mocy bezrefleksyjnej rezygnacji z własnej podmiotowości. Uczestnicy organizacji funkcjonują tutaj zatem na poziomie „tożsamości roli", który nie dopuszcza zaangażowania w działania odbiegające od założonych norm grupowych ze względu na brak świadomości problemu prawomocności tych norm ${ }^{36}$.

Trzeci typ wspólnoty to „wspólnota jako zadanie”, która urzeczywistniana jest na mocy „dialogowo uzgadnianych zasad jej kreacji”"37. Podmiotowośći twórczość jednostek jest warunkiem koniecznym do jej istnienia, a cele grupowe stanowią swoistą pomoc $\mathrm{w}$ możliwości realizacji celów indywidualnych, gdzie jednostki autonomicznie akceptują (lub podają w wątpliwość) słuszność normatywną tak własnych, jak i grupowych celów i na mocy krytycznego dialogu rozpatrują ich zgodność. Wspólnota ta konstytuowana jest przez jednostki znajdujące się na najwyższym, to znaczy postkonwencjonalnym poziomie rozwoju moralnego, charakteryzującym się napięciem aksjonormatywnym związanym z umiejętnością podawania $\mathrm{w}$ wątpliwość obowiązujących norm, wartości, zasad, celów czy interesów, jeżeli te ograniczają jednostkową podmiotowość i uniemożliwiają samorealizację (kompetencja do działania w sporze) ${ }^{38}$.

Zauważmy teraz, że - jak wynika z badań Banaszaka ${ }^{39}$ - polski menedżer, który ukończył edukację menedżerską, charakteryzuje się wysokim poziomem kapitału społecznego, z jednoczesnym miernym poziomem kapitału kulturowego. Co prawda nie jest uprawnione uogólnianie wniosków wynikających z badań empirycznych na całą populację menedżerów w Polsce, ale mimo to rezultaty przytaczanych badań dają do myślenia. Sprawdza się bowiem symptomatyczna sugestia Witkowskiego za Pierrem Bourdieu, że szczególnie w obrębie zjawisk naznaczonych sukcesem społecznym należy widzieć możliwość istnienia patologii kulturowych ${ }^{40}$.

Wniosek o wysokim poziomie kapitału społecznego wynika z faktu, iż badani menedżerowie posiadają silną motywację do rozbudowywania sieci kontaktów

35 Ibidem, s. 166.

36 Ibidem, s. 183.

37 Ibidem, s. 166.

38 Ibidem, s. 183.

39 S. Banaszak, Edukacja menedżerska w społeczeństwie wspótczesnym. Studium teoretyczno-empiryczne, Wydawnictwo Naukowe UAM, Poznań 2011, s. 188-280. Badania przeprowadzono w latach 2006-2008 przy wykorzystaniu techniki wywiadu pogłębionego (31 respondentów), ankiety (211 respondentów) i analizy zawartości (portal społecznościowy GoldenLine).

40 L. Witkowski, Jaka kultura? (tezy, dopowiedzenia i podsumowanie), [w:] Jaka kultura? Jaki dyskurs? Sfera publiczna a spory o edukację, pedagogikę i zarządzanie, pod red. M. Jaworskiej-Witkowskiej, „Pedagogium", Szczecin 2008, s. 19-49. 
z osobami, dzięki którym mogą uzyskać egoistyczną korzyść, do nieformalnego popierania głównie tych, którzy mogą im coś zaoferować w zamian, czy do podejmowania działań według logiki wzajemnego „załatwiania” najkorzystniejszych opcji. Panuje powszechna wśród respondentów opinia, że sukces zawodowy warunkowany jest przede wszystkim przez kapitał społeczny, rozumiany jako odpowiednie znajomości i dobre kontakty. Przedkonwencjonalny poziom rozwoju moralnego i orientacja radarowa, związana z podejmowaniem działań mających na celu realizację egoistycznego interesu i uzgadnianiem go z każdym dominującym interesem w otoczeniu, widoczne są tu gołym okiem.

Działania badanych menedżerów zdominowane są przez racjonalność instrumentalną, gdzie środkiem mającym pozwolić osiągać cel ekonomiczny są nie tylko teorie zarządzania traktowane jako gotowe recepty na sukces, ale także ludzie w organizacji, których traktuje się przedmiotowo jako manipulowalny zasób ekonomiczny. Idzie to $\mathrm{w}$ parze $\mathrm{z}$ brakiem potrzeby kierowania się $\mathrm{w}$ rzeczywistości organizacyjnej zasadami etycznymi i podporządkowaniem ustalonym procedurom, względem których przyjmuje się uległy konformizm. Zarządzanie traktowane jest przez menedżerów jako narzędzie pozwalające eliminować opór pracowniczy i postawy nonkonformistyczne: przyjmuje się, że im wyższy poziom bezkrytycznej akceptacji dla dominujących norm i wartości w organizacji, tym większa szansa na realizację z góry przyjętych i narzucanych celów organizacyjnych ${ }^{41}$. Zatrzymanie się $\mathrm{w}$ rozwoju moralnym na konwencjonalnym poziomie "tożsamości roli", skutkujące utratą indywidualnej podmiotowości i swoistą „korozją charakteru"42, to kolejna cecha określająca sposób funkcjonowania menedżerów w Polsce.

Niski poziom kapitału kulturowego odzwierciedla się w miernych kompetencjach komunikacyjnych badanych menedżerów, a także w braku zdolności do dokonywania krytycznej refleksji. Brak umiejętności w posługiwaniu się poprawną polszczyzną i w wysławianiu się przy pomocy logicznej konstrukcji zdań i dłuższych narracji to jeden z przejawów braku kompetencji kulturowych - kolejny to brak umiejętności prowadzenia refleksyjnego dialogu opartego na sile argumentu i stosowanie argumentu siły $\mathrm{w}$ postaci przemocy symbolicznej względem podwładnych. Symptomatyczne jest $w$ tym kontekście to, że większość badanych przez Banaszaka menedżerów zgadza się co do konieczności stosowania krzyku jako impulsu motywacyjnego, a także pozytywnie ocenia strategię bycia bezwzględnym w stosunku do podwładnych.

Obraz nędzy kulturowej badanych menedżerów i ich braku kompetencji w zakresie zarządzania dopełnia brak poczucia braku, odzwierciedlony w wyso-

41 Pozytywne ocenianie postaw ukierunkowanych na bezkrytyczny konformizm w organizacji to cecha charakterystyczna polskiej rzeczywistości organizacyjnej, co zresztą potwierdzają inne badania, zob. np. I. Stańczyk, J. Bugaj, T. Oleksyn, Diagnoza i kierunki zmian w zarządzaniu zasobami ludzkimi w przedsiębiorstwach z Listy 500. Raport z badań, Oficyna Wydawnicza SGH, Warszawa 2011, s. 119-128.

42 R. Sennett, Korozja charakteru. Osobiste konsekwencje pracy w nowym kapitalizmie, tłum. J. Dzierzgowski, Ł. Mikołajewski, Wyd. MUZA, Warszawa 2006. 
kim poczuciu sprawstwa, wysokim mniemaniu o sobie, demonstracji pewności siebie za pomocą materialnych atrybutów (samochody, zegarki, gadżety), z jednoczesnym przypisywaniem podwładnym cech leniwości i braku odpowiednich kompetencji. Deficyt kompetencji kulturowych polskich menedżerów staje się jeszcze bardziej przerażający, gdy uświadomimy sobie, że menedżerowie stanowią istotną grupę odniesienia dla pozostałych pracowników organizacji, dostarczając znaczących wzorców etycznych. Jak łatwo się domyślić, w tej sytuacji o reprodukcję analfabetyzmu kulturowego ukrytego pod płaszczykiem wygodnego naśladownictwa i sukcesu ekonomicznego nietrudno.

W kierunku racjonalności emancypacyjnej etyka czytania jako sposób bycia menedżera

Pułap postkonwencjonalnego rozwoju moralnego i przygotowania do działania w profilu wspólnoty jako zadania wydaje się być na dzień dzisiejszy nieosiągalny dla polskich menedżerów, głównie z uwagi na braki na płaszczyźnie edukacji. W miernym poziomie kapitału kulturowego wyraźnie widać skutki braku krytycznych dyskusji podczas zajęć, braku kontaktu z lekturami charakteryzującymi się bogatym potencjałem epistemologicznym prowokującym do refleksji i skutki braku wyjścia poza przeekonomizowaną perspektywę widzenia rzeczywistości (w tym organizacji i zarządzania), redukującą wymiar kształcenia do próby odpowiedzi na jałowe pytanie, jak odnieść sukces ekonomiczny za pomocą dostępnych środków.

Jak zauważa Banaszak, „zarządcy współczesnych organizacji, choć formalnie dobrze wyedukowani, nie dysponują wartościową wiedzą w zakresach: ludzkiej natury, potrzeb ludzkich, społecznych funkcji zakładu pracy, zasad budowania zespołów itp." ${ }^{43}$ Jest to pokłosie zamknięcia dyscyplinarnego nauk o zarządzaniu w Polsce na wpływy humanistyczne, a także konsekwencja pozoru kontaktu z wiedzą humanistyczną, która bardzo często stanowi jedynie ozdobnik niemający większego znaczenia dla impotentów intelektualnych uwiedzionych rajem twardych liczb i „faktów”. Widać to chociażby po redukcji w procesach kształcenia w Polsce zagadnień etycznych do kilkudziesięciu godzin zajęć z etyki, które dodatkowo zazwyczaj przybierają formę rytualizacji pozoru nabywania wiedzy, gdyż studentom zazwyczaj proponuje się jałowe zapamiętywanie informacji na temat cech tzw. systemów etycznych, bez próby inicjowania dyskusji.

Edukacja menedżerska w Polsce wymaga przesunięcia punktu ciężkości z założeń normatywnych wynikających z racjonalności instrumentalnej na rzecz racjonalności emancypacyjnej, która stanowi bazę dla wysiłków podejmowanych w nurcie krytycznej edukacji menedżerskiej. Interes emancypacyjny nurtu krytycznego w kontekście edukacyjnym ukierunkowany jest na proces upełnomocnienia zarówno studentów jak i nauczycieli i pod kątem potencjału upełnomocnienia

43 S. Banaszak, Edukacja menedżerska..., s. 197. 
analizowane są warunki kształcenia menedżerskiego. Głównym punktem zainteresowania „Critical Management Education” są teoretyczne uwarunkowania konstytuujące możliwość urzeczywistnienia na gruncie edukacji menedżerskiej edukacji obywatelskiej. Krytycznemu oglądowi poddawane są zatem treści używane w procesach dydaktycznych czy jakość komunikacji w sali dydaktycznej warunkująca realność nabywania kapitału kulturowego.

Pytania badawcze, jakie należy postawić z perspektywy krytycznej, mogą oscylować wokół następujących zagadnień: czy użyte treści kształcenia zawierają potencjał pluralizmu epistemologicznego (paradygmatycznego) pozwalającego na krytyczne i wielowymiarowe spojrzenie na rzeczywistość organizacyjną czy może stanowią zamknięte monoprzekazy, które charakteryzują się fundamentalizmem epistemologicznym, generując bezrefleksyjność odbioru przez uwiedzenie pozytywistyczną lub/i poradnikową formułą? Czy sposób odbioru tych treści oparty jest na krytycznej refleksyjności i realnym dialogu z autorytetami symbolicznymi, wywodzącym się z etyki czytania związanej z przeżyciem, przebudzeniem i przemianą podmiotu poznającego, czy może na bezrefleksyjnym, autorytarnym naśladowaniu treści podejmowanym w imię złudnego, instrumentalnego celu oswojenia informacji zredukowanych do pytania, jak osiągnąć wyższą efektywność ekonomiczną organizacji? Czy pomiędzy nauczycielem i studentami istnieje przestrzeń realnego, krytycznego dialogu opartego na pobudzającej wymianie argumentów i poszerzaniu wyobraźni humanistycznej i organizacyjnej, czy na autorytarnym narzucaniu treści do bezrefleksyjnego zapamiętania?

Im większa otwartość krytyczna na poruszane problemy czy na analizowane teksty w procesie dydaktycznym oraz im większa doza otwartości na krytyczną dyskusję, tym większa szansa na realizację potencjału emancypacyjnego na płaszczyźnie edukacji menedżerskiej. Potencjał ten pozwala na uświadamianie patologii opresyjnych relacji władzy, dominacji ekonomizmu czy nierówności płciowej tak w tekstach zarządzania, w praktyce życia organizacyjnego, jak i na płaszczyźnie edukacji. Warto raz jeszcze zaakcentować emancypacyjne znaczenie krytyki w CME, które ma prowadzić do zmian w rzeczywistości w intencji troski o ujawnianie patologii kulturowych, a nie sprowadzać się na przykład jedynie do rozważania problemu nieprzystawalności wiedzy nabywanej w toku kształcenia do praktyki zarządzania i organizowania.

Dążenie do realizacji celu emancypacyjnego w edukacji menedżerskiej w Polsce musi wiązać się dzisiaj z podjęciem określonych strategii zmian szczególnie na płaszczyźnie curriculum szkół biznesu czy kursów uniwersyteckich, w sferze komunikacji pomiędzy nauczycielami i studentami, a także pomiędzy treściami kształcenia i ich odbiorcami. Wspólnym mianownikiem tych strategii zdaje się być konieczność oparcia ich założeń normatywnych na idei krytycznej performatywności, która wymaga wzbogacenia procesów kształcenia o element nabywania wiedzy poprzez refleksyjne działanie ${ }^{44}$.

44 A. Contu, Critical Management..., s. 545. 
Po pierwsze zasadne wydaje się zdecydowane wzbogacenie programów kształcenia o teorie krytyczne, które pozwoliłyby na refleksyjny dystans względem przeekonomizowanych, opartych na imperatywie technicznym treści obecnych w głównym nurcie zarządzania, przyczyniając się do ich delegitymizacji, denaturalizacji i obalenia mitu o braku dla nich alternatywy. Wykorzystanie tych teorii pozwoliłoby zatem na swoistą dewiację od głównego nurtu, przesuwając punkt ciężkości refleksji z instrumentalnych rozważań nad środkami potrzebnymi do osiągnięcia sukcesu ekonomicznego organizacji, na rzecz problemów etycznych, takich jak kwestie nierówności, opresji czy władzy. Poprzez zapośredniczenie myślenia w kategoriach paradoksów, antynomii czy dylematów etycznych nauczyciele i studenci uzyskaliby możliwość rozwoju świadomości na temat polityczności zarządzania i organizowania, co zwrotnie rzutowałoby na umiejętność dostrzeżenia złożoności normatywnej rzeczywistości organizacyjnej i bardziej sprawnego w niej działania.

Po drugie programy kształcenia warto nasycać dziedzictwem symbolicznym sztuki. Dla przykładu literatura (ale także film czy teatr) jest wartościowym medium przekazu wiedzy na temat zarządzania, pozwalając dostrzegać nierozpoznawalne $w$ dyskursie naukowym paradoksy życia organizacyjnego ${ }^{45}$. Rozwój wyobraźni humanistycznej przez współczesnego menedżera na mocy kontaktu $\mathrm{z}$ wytworami sztuki wydaje się być fundamentalny z uwagi na coraz większą złożoność normatywną sfery organizacji, a także konieczność posługiwania się w procesach zarządzania intuicją i wiedzą utajoną ${ }^{46}$.

Zauważmy jednak, że samo nasycanie programów kształcenia teorią krytyczną czy literaturą nie przyniesie pożądanych korzyści emancypacyjnych, jeżeli kontakt z kulturą symboliczną oparty zostanie na pozornej komunikacji. W kontekście myślenia o kondycji edukacji menedżerskiej powyższa sugestia wskazuje na to, że samo nasycanie programów kształcenia treściami humanistycznymi nie wystarczy, aby edukacja ta mogła spełnić swoją funkcję poszerzania refleksyjności wśród podmiotów zaangażowanych $\mathrm{w}$ kształcenie. Samo poszerzanie punktów widzenia bez zdolności do ich uzasadnienia i negocjowania znaczeń skutkować może, jak zauważa Andrzej M. Kaniowski za Ortegą y Gassetem ${ }^{47}$, postawą człowieka pośledniego, która wiąże się z brakiem umiejętności dokonywania indywidualnych przemyśleń, $\mathrm{z}$ jednoczesnym poczuciem posiadania słusznego zdania i prawa do narzucania go innym. Kryje się tu zatem pułapka autorytaryzmu własnych sądów, związana z brakiem otwartości na ich renegocjowanie.

45 Co zostało już dawno temu dostrzeżone na Zachodzie, zob. Good Novels, Better Management. Reading Organizational Realities in Fiction, B. Czarniawska-Joerges, P. Guillet de Monthoux (eds), Harwood Academic Publishers, Chur 1994.

46 M. Kostera, Organizacje i archetypy, Wolters Kluwer Polska, Warszawa 2010.

47 A.M. Kaniowski, Dyskurs publiczny a podstawy nowoczesnej kultury: kryzys jako wyzwanie, [w:] Jaka kultura? Jaki dyskurs? Sfera publiczna a spory o edukację, pedagogikę i zarządzanie, pod red. M. Jaworskiej-Witkowskiej, „Pedagogium”, Szczecin 2008, s. 77-92. 
Kwestia etyki czytania jako sposobu bycia jest tutaj kluczowa, bo rozstrzyga o efektach kontaktu z przyswajaną treścią48. Na płaszczyźnie kształcenia - w tym i menedżerów - urzeczywistnienie upełnomocnienia wymaga przede wszystkim stworzenia warunków do wzbogacania kapitału symbolicznego, co zależy od „gotowości do włączenia do treści edukacyjnych możliwości wytwarzania wiedzy z pozycji doświadczenia"49. Etyczność w omawianym zakresie wymaga w pierwszej kolejności tego, aby procesy dydaktyczne osadzić na wizji autorytetu symbolicznego jako kogoś, z kim warto dyskutować, a nie kogo trzeba naśladować50. Niezależnie od formy, jaką przybiera treść (podręcznik akademicki z dyscypliny nauk o zarządzaniu, autorska książka naukowa na temat zarządzania, poradnik z przestrzeni pop-managementu, powieść), jej odbiór musi wiązać się z próbą podjęcia dyskusji z autorem z jednoczesnym zaniechaniem strategii obiektywizacji opartej na próbie odpowiedzi na jałowe pytanie, „co autor ma na myśli?”.

Zasadne staje się zatem wykorzystanie strategii drapieżnej pokory ${ }^{51}$, która pozwala wyszukiwać emocjonalnie ważne dla czytelnika momenty wybuchowe w tekście, bez uległości względem autorytetu symbolicznego, ale z jednoczesnym unikaniem autorytarności własnego stanowiska normatywnego. Zasadne wydaje się stwierdzenie, że bez przeżycia treści nie ma jej rozumienia, co skutkuje jedynie oswojeniem pewnego zasobu informacji, które nie mają szans na stanie się pracującą w nas i rozwijającą głębię spojrzenia i jakość uzasadnień wiedzą.

Dodajmy, że z perspektywy idei krytycznej performatywności ważnym elementem wzbogacającym procesy kształcenia menedżerskiego jest umożliwienie studentom nabywania wiedzy poprzez partycypację w warunkach organizacyjnych, a także poprzez kontakt z pracującymi menedżerami. Możliwość rozwiązywania problemów organizacyjnych w czasie rzeczywistym występujących w danej organizacji (np. poprzez wykorzystanie studium przypadku i pracy grupowej w przestrzeni organizacyjnej) wydaje się być kluczowe z perspektywy rozwoju kompetencji kulturowych i zawodowych. Podobnie realny dialog z menedżerami pozwolić może na wzbogacenie wyobraźni organizacyjnej i zapoznanie się ze złożonością pracy menedżerskiej. Aby jednak ten typ kształcenia przyniósł realne korzyści i nie stał się pozorem uprawianym pod przykrywką marketingu, partycypacja w warunkach organizacyjnych nie może sprowadzać się do wycieczki promocyjnej po zakładzie pracy, a kontakt z menedżerem do pustego wykładu guru promującego swoją markę. Ponadto trzeba pamiętać, że partycypacja w warunkach organizacyjnych może stać się zmarnowaną okazją na rozwój

\footnotetext{
48 M. Zawadzki, Etyka czytania jako sposób bycia, „Twórczość” 2010, nr 8(777), s. 129-131.

49 L. Witkowski, Wyzwania autorytetu ..., s. 448.

50 Ibidem; L. Witkowski, Historie autorytetu wobec kultury i edukacji, Oficyna Wydawnicza „Impuls”, Kraków 2011.

51 L. Witkowski, Wstęp do problemu fenomenologii czytania (uwagi nie tylko seminaryjne), [w:] Między pedagogika, filozofia i kulturą. Studia, eseje, szkice; Tenże, t. III Tryptyku Edukacyjnego, Instytut Badań Edukacyjnych, Warszawa 2007, s. 29-66.
} 
kompetencji menedżerskich w momencie, gdy w sali dydaktycznej będzie trwał pozór kształcenia, o którym pisałem wyżej.

\section{Zakończenie}

Wdrażanie idei krytycznej edukacji menedżerskiej w Polsce wydaje się zadaniem koniecznym, fascynującym, ale i szalenie trudnym. Założenie dotyczące konieczności uczynienia praktyki krytycznej kolektywnym przedsięwzięciem w naukach o zarządzaniu, edukacji menedżerskiej i praktyce życia organizacyjnego napotyka szereg przeszkód. Po pierwsze zdecydowana większość osób mających kontakt z zarządzaniem utożsamia tę dyscyplinę z praktyką skutecznego zarabiania pieniędzy, dodatkowo zamykając swoje horyzonty myślenia w ciasnym gorsecie dyscyplinarnym ekonomii. W związku z tym konieczne staje się znalezienie sposobu na konstytucję przestrzeni komunikacyjnej, która pozwoliłaby na realny, transdyscyplinarny dialog pomiędzy przedstawicielami głównego nurtu zarządzania i badaczami wywodzącymi się z nauk humanistycznych, którzy zainteresowani są rozwojem nauk o zarządzaniu. Być może musi to pójść w parze z odebraniem nauk o zarządzaniu osobom, które roszczą sobie miano do bycia ich jedynymi rzecznikami i które starają się negować dorobek wielkich autorytetów symbolicznych, nie zasługujących przecież na wykorzystanie na polu zarządzania z uwagi na przypisaną etykietkę badaczy społecznych (takich jak np. Habermas).

Po drugie warto zwrócić uwagę na problem masowości kształcenia na kierunkach związanych z zarządzaniem, które od lat sytuują się na czele najbardziej popularnych kierunków studiów w Polsce. Kształcenie emancypacyjne wymaga bezpośredniego kontaktu pomiędzy nauczycielem i studentami, który musi być oparty na relacji mistrz-uczeń. Nieproporcjonalnie mała liczba nauczycieli w stosunku do liczby studentów nie pozwala na urzeczywistnienie takiej relacji, sprowadzając kształcenie do pozoru opartego na masowym zdobywaniu nic nieznaczących w sensie kulturowym dyplomów. Mało tego, jak wskazują badania Aleksandra Sulejewicza i Mahmooda Zaidi, kadra nauczycielska związana z edukacją menedżerską $w$ Polsce charakteryzuje się zacofaniem intelektualnym związanym z posiadaniem przestarzałych informacji na temat zarządzania, z jednoczesnym ich zrytualizowanym odtwarzaniem $\mathrm{w}$ procesie dydaktycznym $\mathrm{w}$ postaci prezentacji multimedialnych, zazwyczaj w kilku uczelniach jednocześnie (co powoduje, że nie ma czasu na samokształcenie). W skład owej kadry często wchodzą tzw. "pułkownicy” - pracownicy naukowi piszący nic nieznaczące w sensie kulturowym, ale dające awans i prestiż społeczny książki, których jedyną rolą jest zaleganie na półkach ${ }^{52}$.

52 A. Sulejewicz, M. A. Zaidi, Beyond MBA. Management Education in Transitional Economies, Warsaw School of Economics, Warsaw 2010, s. 143-152. 
Wspomniane patologie kulturowe to jedynie kropla w morzu nędzy kulturowej edukacji menedżerskiej w Polsce, dlatego konieczne zmiany wymagają szybkości i radykalności reakcji. Warto w tym kontekście zauważyć, że nie można zamykać poszukiwań przyczyn patologii kulturowych w świecie zarządzania czy edukacji menedżerskiej w stwierdzeniu, że rzeczywistość rynkowa i kapitalistyczna takie-już-są i same $\mathrm{w}$ sobie $\mathrm{w}$ sposób naturalny są spatologizowane. To błędne założenie, dodatkowo stanowiące wygodne alibi dla impotentów intelektualnych niepotrafiących dostrzec wartości w poważnej refleksji filozoficznej nad sferą ekonomii i zarządzania.

Warto także podkreślić, że krytyczna edukacja menedżerska nie może być traktowana jako jeden z nurtów czy modeli badawczych (lub dydaktycznych) wchodzących w skład edukacji menedżerskiej w ogóle. Podobnie jak pedagogika krytyczna nie jest jednym z pól konstytuujących przestrzeń badawczą pedagogiki. Pedagogika albo jest krytyczna, albo nie istnieje (choć można skutecznie podtrzymywać pozór jej istnienia) ${ }^{53}$ - podobnie krytyczność zaświadcza o realności istnienia edukacji menedżerskiej. To paradoksalne założenie pozwala walczyć z niebezpieczeństwem sprowadzenia nurtu krytycznej edukacji menedżerskiej (jak i pedagogiki krytycznej) do roli oswojonej, wymienialnej i użytecznej na rynku naukowym idei. Realizacja tego założenia w praktyce wymaga między innymi przezwyciężenia tendencji ekskluzywistycznych (tzw. kartelizacji) wśród osób zajmujących się pedagogiką krytyczną i krytyką edukacji menedżerskiej, na rzecz strategii otwartości i wprowadzania za pośrednictwem kultury symbolicznej i kapitału symbolicznego realnych zmian w procesach kształcenia menedżerskiego.

Walka o radykalną zmianę w kierunku krytycznej otwartości emancypacyjnej, przezwyciężającej analfabetyzm kulturowy polskich menedżerów i osób zajmujących się naukami o zarządzaniu, jest już opóźniona.

\section{Summary}

\section{Denaturalisation of instrumental rationality in the management education in Poland}

In the article I diagnose cultural pathologies in management education in Poland using the critical tools proposed by the "Critical Management Education". The main aim of my reflection is to denaturalize an assumption, that management education should be located on economic paradigm with a domination of instrumental rationality. Reflection is based on my own theoretical research, in which I use such Lech Witkowski's ideas as ethics of reading, symbolic authority and moral development triad. I also use the empirical research about Polish managers and management education.

53 Dziękuję Panu profesorowi Lechowi Witkowskiemu za zwrócenie mojej uwagi na tę tezę podczas wykładu plenarnego rozpoczynającego konferencję „Pedagogika krytyczna dziś. Pytania o teorię i praktykę" (Instytut Pedagogiki Uniwersytetu Gdańskiego, 28-29 maja 2012 r.). 